International Journal of Engineering \& Technology, $7(2.31)(2018) 127-130$
International Journal of Engineering \& Technology
SPC
Website: www.sciencepubco.com/index.php/IJET
Research paper

\title{
A parametric study of residual stress in plate
}

\author{
Nikhil S. Agrawal ${ }^{1}$, P.B. Kulkarni², P.D. Pachpor ${ }^{3}$, R.N. Khapre ${ }^{4}$, Dipak Nakhate ${ }^{5}$ \\ ${ }^{1}$ Assistant Professor, Department of Civil Engineering, Shri. Ramdeobaba College of Engineering and Management, \\ Nagpur, Maharashtra, India. \\ ${ }^{2}$ Associate Professor, Department of Civil Engineering, Shri. Ramdeobaba College of Engineering and Management, \\ Nagpur, Maharashtra, India. \\ ${ }^{3}$ Professor, Department of Civil Engineering, Shri. Ramdeobaba College of Engineering and Management, Nagpur, Maharashtra, India. \\ ${ }^{4}$ Associate Professor, Department of Civil Engineering, Shri.Ramdeobaba College of Engineering and Management, \\ Nagpur, Maharashtra, India. \\ ${ }^{5}$ P.G. Student, Department of Civil Engineering, Shri. Ramdeobaba College of Engineering and Management, \\ Nagpur, Maharashtra, India. \\ *Corresponding author E-mail:agrawalns9@ rknec.edu
}

\begin{abstract}
Residual stress is a process-induced stress in a molded part that exists in the body in the absence of external loading or it exists in steel section of the unloaded state. Residual stress is also termed as 'Locked Stress'. This paper presents to find out this lock stress analytically. The theoretical and analytical inputs are considered in terms of aspect ratio and these results are compared by percentage error. The previous study mentioned many experimental methods by which residual stresses were sorted out. A Plate is a flat surface having thickness small as compared to other two dimensions. Researchers are mainly focused on the treatment of the different plate theories related to Kirchhoff or Reissner/Mindlin. The developed ANSYS finite element model analyzed square and rectangular plate and compared the analytical results in terms of deflection and stress with theoretical results which are obtained from classical theory. Different boundary conditions for different plate size are considered and solved.
\end{abstract}

Keywords: Residual Stress, Slab, Plate, Classical Theory.

\section{Introduction}

Residual stress also defined as, 'those stresses which are already shown signs in the body without any external loadings or any thermal gradients.' In other words, residual stresses in a structural material or component are those stresses which exist in the object without the application of any service or other external loads. The current paper is stressed on the measurement of residual stress. Because of so many reasons, it is very difficult to obtain the distribution of residual stresses using analytical methods. Therefore, software is the easiest way to understand the distribution of residual stresses using analytical methods. A plate is a flat surface having considerably large dimensions as compared to its thickness. A plate can be considered a twodimensional extension of a beam in simple bending. Both Slabs and plates support loads perpendicular to their planes and transmit the load by bending action. A beam has a single moment of resistance while the plate resists bending about two axes. O. C. Zienkiewicz, R.L. Taylor.[1] "The Finite Element Method", has explained finite element formulation for both thick and thin plate, and also provided the mixed formulation for the thick plate. L.Gardner, R.b. Cruesia[12]"Creation of residual stress in stainless steel section(2000)"'In this paper magnitude and distribution of residual stresses in structural steel section have been thoroughly investigate. The few residual stress measurents have been made on structural stainless steel sections. This suggests that established carbon steel residual stress models may not be appropriate for stainless steel.Jaehong Lee, Zafer Gurdalt and O. Hayden Griffin Jr. [14] Suggested in the classical theories of plates and shells are an important application of the theory of elasticity, which deals with relationships of forces, displacements, stresses, and strains in an elastic body. When a solid body is subjected to external forces, it deforms, producing internal strains and stresses.

The deformation depends on the geometrical configuration of the body, on applied loading, and on the mechanical properties of its material. Properties are the same in all directions and at all points.

\section{Classification of Plates}

On the basis of Classical Theory [14]

The bending properties of a plate depend greatly on its thickness, hence in classical theory,

we have following groups:

\section{Thin plates}

a) Thin plates with small deformation

b) Thin plates with large deformation

\section{Thick plates}

On the basis of shapes plates are classified as

1. Rectangular Plate

2. Square Plate

3. Triangular Plate

4. Circular Plate

5. Skew Plate

6. Quadrilateral Plate

7. Other shapes. 


\section{Problem Statement}

In many areas of structural design, we require analysis of plates subjected to lateral loads. It is well known from the elastic theory of plates, that the classical solution involves tedious calculations. As a numerical solution to the problem, numbers of finite element models are developed.

It is not easy to find residual stresses by using any software. we generally use ANSYS and ABAQUS software. In ANSYS finite element formulation is used for both Thick and Thin Plates. In this project, results of deflection, bending stress of plates using ANSYS are compared with the theoretical results as obtained from plate and shale theory. A parametric study of all these plates with edges simply supported by a uniformly distributed load has been carried out. Generally, residual stresses are found by practical demonstration. There are various practical methods to find out residual stresses in steel member.

\section{Objective and scope of this dissertation}

Residual stresses have the same role in a structure's strength as common mechanical stresses. However, while stress due to external loads can be calculated with a degree of accuracy by various method but residual stresses are difficult to calculate. The main objective of this work is to track out the effect of residual stresses in plate element, which is then correlated with the slab as a plate element. The study is focused on the effect of residual stress in plate modelled in ANSYS and their performance in terms of behavior during analysis.

The specific objectives of this work include:

1. Behavior of plates subjected to lateral loads with different boundary conditions.

2. To track out "locked stress" (Residual stress) in the steel plate by using stress-strain relationship.

3. Comparison of results of deflection and bending stress obtained from ANSYS which is for residual stress in terms of deflection and bending stress.

\section{Methodologies}

In these paper square plates, rectangular plates subjected to uniform pressure, with the simply supported condition have been analyzed using ANSYS. The different size with different boundary condition is applying. The modulus of elasticity of steel and poisons ratio $200 \mathrm{GPa}, 0.3$ respectively same for all plates. The different boundary condition is given below:

1. Four sides are simply supported

Boundary condition (Four sides are simply supported) taking three different sizes of the plate and analyzed these plates in ANSYS and find out the result accurately. Sizes of these two different plates are given below:
a. $\quad 60 \mathrm{~mm} \times 120 \mathrm{~mm} \times 2 \mathrm{~mm}$
b. $\quad 60 \mathrm{~mm} \times 60 \mathrm{~mm} \times 2 \mathrm{~mm}$

\section{Result}

i) For Size of Rectangular Plate $(60 \mathrm{~mm} \times 120 \mathrm{~mm} \times 2 \mathrm{~mm})$ with Uniform Pressure (1 MPa)

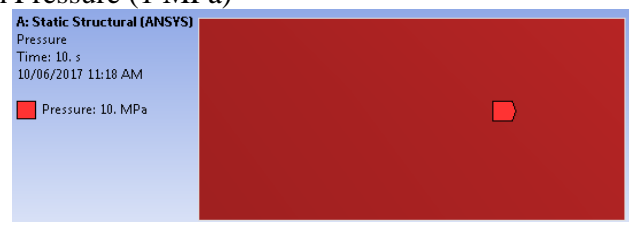

Figure 1.1: Pressure contour for plate

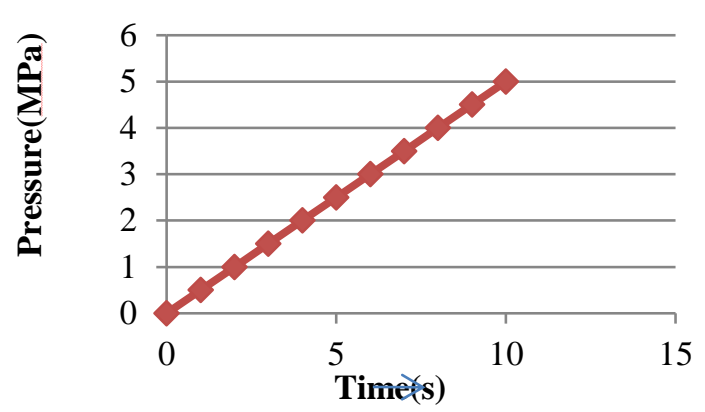

Graph 1.1: Time vs. Pressure

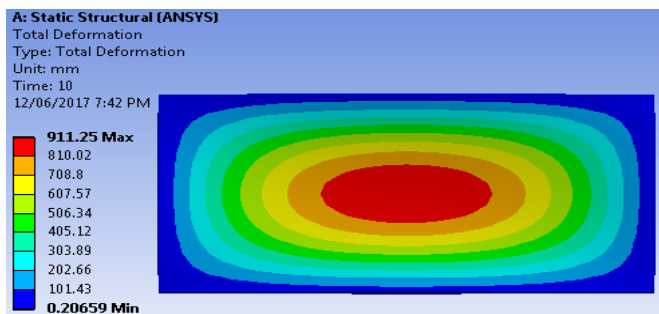

Figure 1.2: Deflection contour for plate

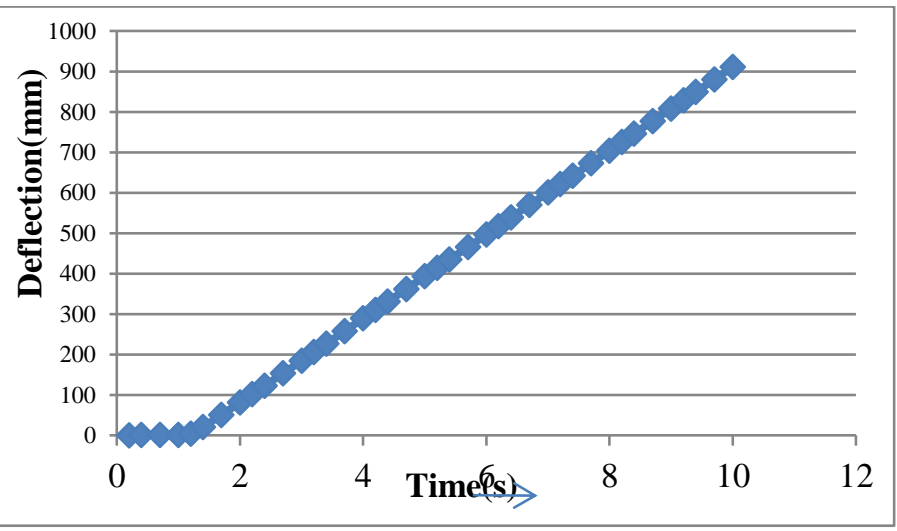

Graph 1.2: Time vs. Deflection

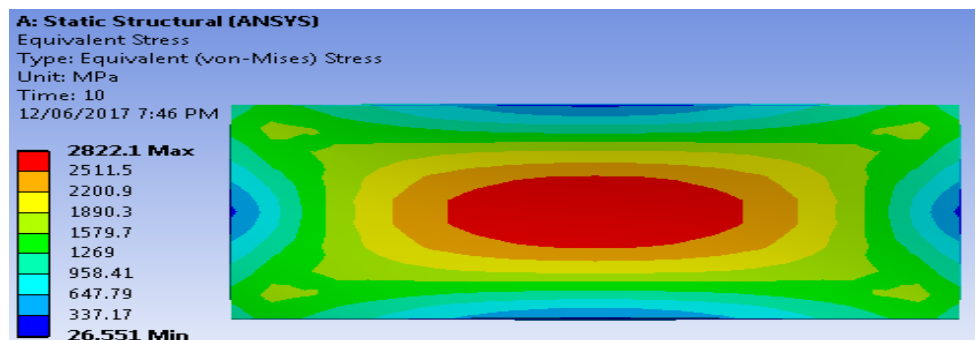

Figure 1.3: Stress contour for plate

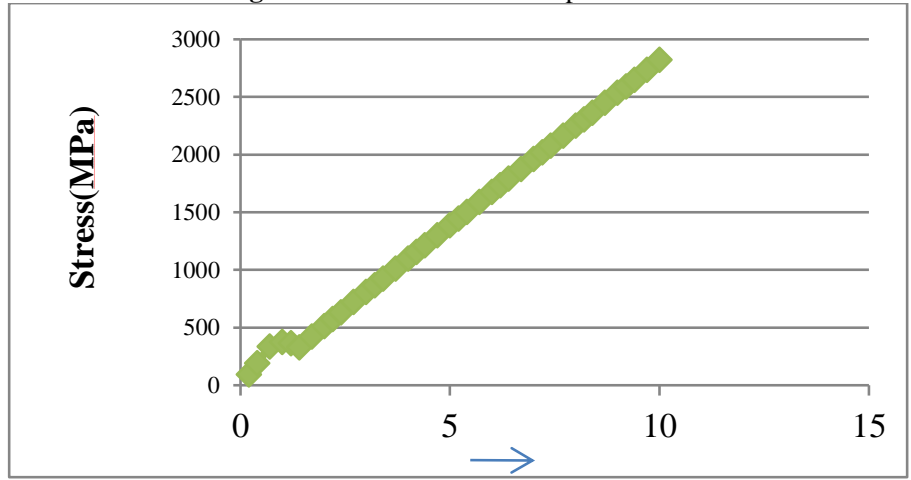

Graph 1.3: Time vs. Stress 


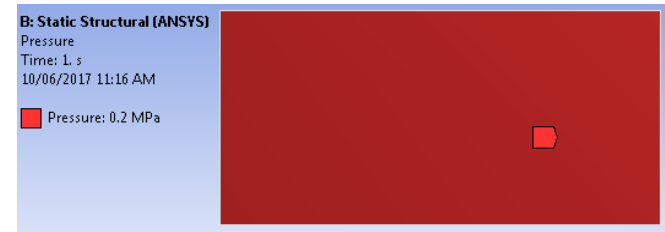

Figure 1.4: Pressure contour for plate

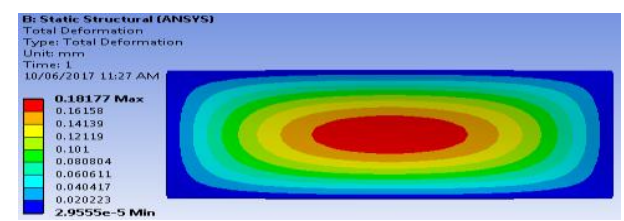

Figure 1.5: Deflection contour for plate

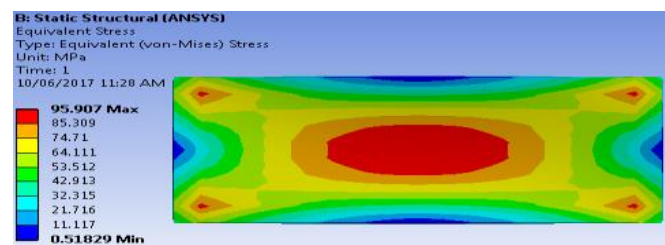

Figure 1.6: Stress contour for plate

Table 1.1: Pressure, Deflection and Stress Contour for Plate

\begin{tabular}{|l|l|l|}
\hline Pressure(MPa) & Deflection(mm) & Stress(MPa) \\
\hline 0.2 & 0.1817 & 95.907 \\
\hline
\end{tabular}

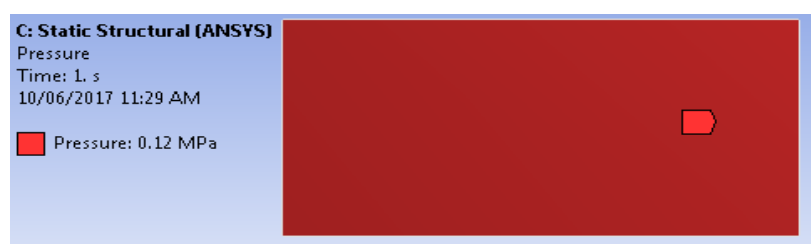

Figure 1.7: Pressure contour for plate

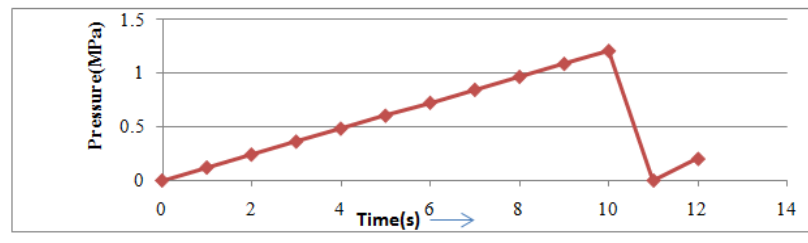

Graph 1.4: Time vs. Pressure

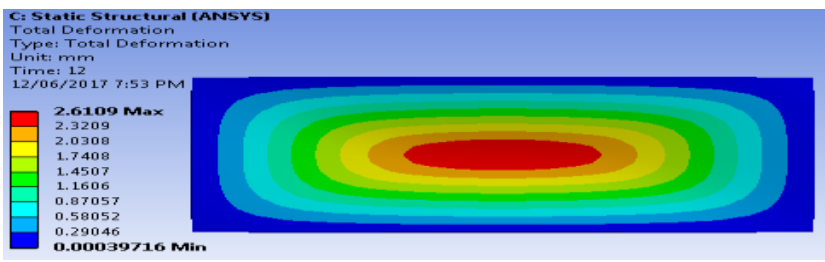

Figure 1.8: Deflection contour for plate

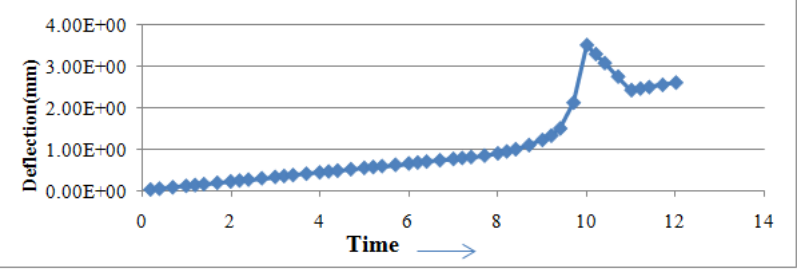

Graph 1.5: Time vs. Deflection

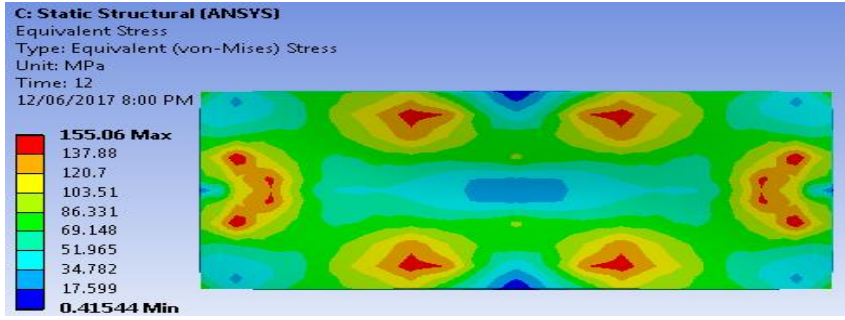

Figure 1.8: Stress contour for plate

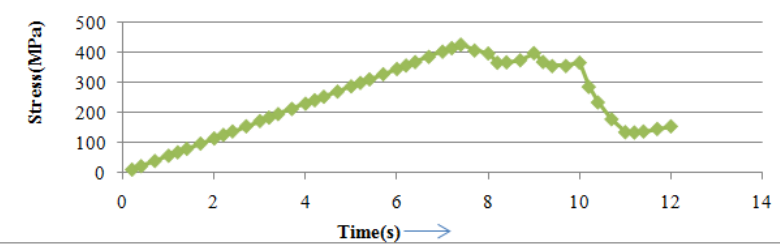

Graph 1.6: Time vs. Stress

Table 2: Four Sides are Simply Supported with Size $(60 x 120 x 2) \mathrm{mm}$

\begin{tabular}{|c|c|c|c|c|c|c|}
\hline \multirow{2}{*}{$\begin{array}{l}\text { Sr. } \\
\text { NO. }\end{array}$} & \multirow[t]{2}{*}{ Loading } & \multirow[t]{2}{*}{ Result at Centre } & \multirow{2}{*}{$\begin{array}{l}\text { Theoretical } \\
\text { Results }\end{array}$} & \multicolumn{2}{|c|}{ Analytical Results } & \multirow{2}{*}{$\begin{array}{l}\% \text { Error } \\
(\mathrm{T} \\
\text { WT.R)/T }\end{array}$} \\
\hline & & & & $\begin{array}{l}\text { With } \\
\text { Residual } \\
\text { Stress }\end{array}$ & $\begin{array}{l}\text { Without } \\
\text { Residual } \\
\text { Stress }\end{array}$ & \\
\hline 1 & Uniform & Deflection $(\mathrm{mm})$ & 0.178 & 0.181 & 0.181 & -1.685 \\
\hline 2 & Loading & Stress $\left(\mathrm{N} / \mathrm{mm}^{2}\right)$ & 108 & 155.06 & 95.907 & 11.19 \\
\hline
\end{tabular}

$\mathrm{T}=$ Theoretical Results

W.R=With Residual Stress

WT.R =Without Residual Stress

Table 3: Four Sides are Simply Supported with Size (60x120x2) mm

\begin{tabular}{|c|c|c|c|c|c|c|}
\hline \multirow{2}{*}{$\begin{array}{l}\text { Sr. } \\
\text { NO. }\end{array}$} & \multirow[t]{2}{*}{ Loading } & \multirow[t]{2}{*}{ Result at Centre } & \multirow{2}{*}{$\begin{array}{l}\text { Theoretical } \\
\text { Results }\end{array}$} & \multicolumn{2}{|c|}{ Analytical Results } & \multirow{2}{*}{$\begin{array}{l}\% \text { Error } \\
(\mathrm{T}- \\
\text { W.R)/T }\end{array}$} \\
\hline & & & & $\begin{array}{l}\text { With } \\
\text { Residual } \\
\text { Stress }\end{array}$ & $\begin{array}{l}\text { Without } \\
\text { Residual } \\
\text { Stress }\end{array}$ & \\
\hline 1 & Uniform & Deflection $(\mathrm{mm})$ & 0.178 & 0.181 & 0.181 & -1.685 \\
\hline 2 & Loading & Stress $\left(\mathrm{N} / \mathrm{mm}^{2}\right)$ & 108 & 155.06 & 95.907 & -43.574 \\
\hline
\end{tabular}

For size of square plate $(60 \mathrm{~mm} \times 60 \mathrm{~mm} \times 2 \mathrm{~mm})$ with uniform pressure (1MPa)

Table 4: Pressure, Deflection and Stress Contour for Plate

\begin{tabular}{|l|l|l|}
\hline Pressure(MPa) & Deflection $(\mathrm{mm})$ & Stress(MPa) \\
\hline 0.34 & 0.1253 & 120.34 \\
\hline
\end{tabular}

Table 5: Four Sides are Simply Supported with Size (60x60x2) mm

\begin{tabular}{|c|c|c|c|c|c|c|}
\hline \multirow{2}{*}{$\begin{array}{l}\text { Sr. } \\
\text { NO. }\end{array}$} & \multirow[t]{2}{*}{ Loading } & \multirow[t]{2}{*}{ Result at Centre } & \multirow{2}{*}{$\begin{array}{l}\text { Theoretical } \\
\text { Results }\end{array}$} & \multicolumn{2}{|c|}{ Analytical Results } & \multirow{2}{*}{$\begin{array}{l}\% \text { Error } \\
(\mathrm{T} \\
\text { WT.R)/T }\end{array}$} \\
\hline & & & & $\begin{array}{l}\text { With } \\
\text { Residual } \\
\text { Stress }\end{array}$ & $\begin{array}{l}\text { Without } \\
\text { Residual } \\
\text { Stress } \\
\end{array}$ & \\
\hline 1 & \multirow{2}{*}{$\begin{array}{l}\text { Uniform } \\
\text { Loading } \\
\end{array}$} & Defl & 0.0645 & 0.0737 & 0.1253 & -2.704 \\
\hline 2 & & Stress $\left(\mathrm{N} / \mathrm{mm}^{2}\right)$ & 132.07 & 70.788 & 120.34 & 8.88 \\
\hline
\end{tabular}

Table 6: Four Sides are Simply Supported with Size (60x60x2) mm

\begin{tabular}{|c|c|c|c|c|c|c|}
\hline \multirow{2}{*}{$\begin{array}{l}\text { Sr. } \\
\text { NO. }\end{array}$} & \multirow[t]{2}{*}{ Loading } & \multirow[t]{2}{*}{ Result at Centre } & \multirow{2}{*}{$\begin{array}{l}\text { Theoretical } \\
\text { Results }\end{array}$} & \multicolumn{2}{|c|}{ Analytical Results } & \multirow{2}{*}{$\begin{array}{l}\text { \% Error } \\
\text { (T - } \\
\text { W.R)/T }\end{array}$} \\
\hline & & & & $\begin{array}{l}\text { With } \\
\text { Residual } \\
\text { Stress }\end{array}$ & $\begin{array}{l}\text { Without } \\
\text { Residual } \\
\text { Stress }\end{array}$ & \\
\hline 1 & Uniform & Deflection $(\mathrm{mm})$ & 0.0645 & 0.0737 & 0.1253 & -14.263 \\
\hline 2 & Loading & Stress $\left(\mathrm{N} / \mathrm{mm}^{2}\right)$ & 132.07 & 70.788 & 120.34 & 46.401 \\
\hline
\end{tabular}

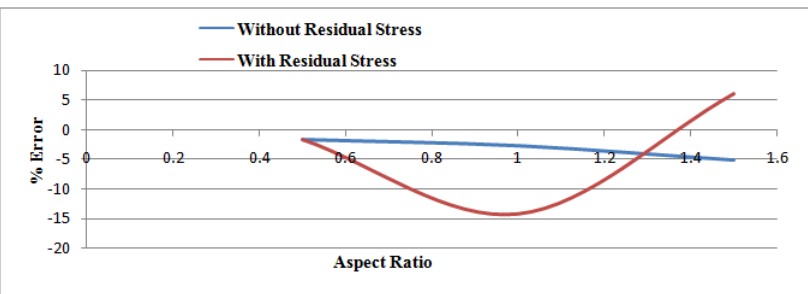

Graph 1.8: A: Aspect Ratio vs. \%Error in Deflection 


\section{Discussion}

For four sides are simply supported

1. In this boundary condition, the different aspect ratio is taken and analyzed plate in ANSYS software and find out the result in terms of deflection and stress.

2. The location of maximum stresses occurs at the centre of the plate.

3. The results of deformation using with and without residual stresses are nearly same as compare to theoretical results.

4. The graph 1.8.A shows that, as the Aspect ratio increases the Percentage error also increases in without residual stresses. Whereas, the percentage error increases and then decreases in with residual stress.

\section{Conclusion}

Normally, residual stresses are difficult to foresee. It is very important to have a reliable method to measure them directly. Here, in this project, we have tried to locate maximum stress (Residual stress) in steel plate with the help of stress-strain relationship. It is very difficult to find out residual stress analytically. An analytical model was constituted to study the effect of residual stress.

1. The analytical model results confirm that initial modulus of elasticity and material non-linearity strongly depends upon the residual stress magnitude.

2. Residual stresses, affect the properties of steel element and due to which strength of material also changes.

3. For square and rectangular plate, the location of maximum stresses changes, because of changing the boundary condition.

4. For square and rectangular plate, the results of deformation using with and without residual stresses are nearly same as compared to theoretical results.

5. For square and rectangular plate, with residual stresses give higher values than without residual stresses, because of adding $20 \%$ extra load in the plate.

6. For four sides are simply supported (Graph 1.8) shows that, as the Aspect ratio increases the Percentage error also increases in without residual stresses. Whereas, the percentage error increases and then decreases in with residual stress.

\section{References}

[1] Zienkiewicz OC \& Taylor RL, The Finite Element Method, Fifth edition, (2000).

[2] Bhavikatti SS, Finite Element Analysis, Second Edition, New Age International Private Ltd, (2005)

[3] Godbole PN, Introduction to Finite Element Method, under publication,(2013)

[4] Kobayashi M, Matsui T \& Murakami Y, "Mechanism of creation of compressive residual stress by shot peening", International Journal of Fatigue, (1998), pp.351-357.

[5] Thiébaud R \& Lebet JP, "Experimental study of residual stresses in thick steel plates", SSRC Annual Stability Conference Proceedings, (2012), pp.17-20.

[6] Kudryavtsev Y \& Kleiman J, "Measurement of residual stresses in welded elements and structures by ultrasonic method. International Institute of Welding", IIW Document XIII-2339, (2010).

[7] Monin VI, Gurova T, Castello X \& Estefen SF, "Analysis of residual stress state in welded steel plates by X-ray diffraction method", Rev. Adv. Mater. Sci, (2009), pp.172-175.

[8] Krishnamoorthy CS, Finite element analysis: theory and programming, Tata McGraw-Hill Education, (2010).

[9] Pilkey WD \& Pilkey WD, Formulas for stress, strain, and structural matrices, New York: J. Wiley, (2005).

[10] Timoshenko S \& Krieger SW, Theory of Plates and Shells, Second Edition, Mc-Graw Hill Book Company,(1959).
[11] Wilson EL, Three Dimensional Static and Dynamic Analysis of Structures, Third Edition, Computer and Structures Inc. Berkeley, California, (2002).

[12] Gardner L \& Cruesia RB, Creation of residual stress in stainless steel section,(2000).

[13] Rossini NS, Dassisti M, Benyounis KY \& Olabi AG, "Methods of measuring residual stresses in components", Materials \& Design, Vol.35, (2012), pp.572-588.

[14] Lee J, Gurdalt Z \& Griffin Jr OH, "Layer wise approach for the Bifurcation problem in laminated Composites with Delaminations", AIAA, Vol.31, No.2,(1993). 